\title{
GENIUS LOCI PADA PERKAMPUNGAN TRADISIONAL SENARU SUKU SASAK KABUPATEN LOMBOK BARAT
}

\author{
Sriany Ersina, ST., MT ${ }^{1}$, Annisa Amalia, ST., M.Si ${ }^{2}$, Sutriani, ST., M.T \\ Jurusan Arsitektur Fakultas Sains \& Teknologi UIN Alauddin Makassar \\ Email: sriany.ersina@uin_alauddin.ac.id,nisa_urban@ymail.com, \\ sutriani.shafa@gmail.com
}

\begin{abstract}
Senaru traditional village located in Senaru Village Lombok West Regency. The existence of a traditional village in response to the demands of home and village which is a form of cohabitation of Sasak as the original inhabitants of this village. Literally, the genius loci is the soul of space and time, locality and region-region where architecture grows and develops that triggers the growth of the spirit of "place" (spirit of place) where the spirit that makes a place that can "live". The genius loci in this study is divided into two, namely the genius loci of the settlement area and genius loci in neigborhood of the traditional village of Sasak tribe in the village of Senaru.
\end{abstract}

Keywords: Genius loci, traditional village, neighborhood, house

\footnotetext{
${ }^{1}$ Dosen Jurusan Teknik Arsitektur UIN Alauddin Makassar

${ }^{2}$ Dosen Jurusan Teknik Arsitektur UIN Alauddin Makassar

${ }^{3}$ Dosen Jurusan Teknik Arsitektur UIN Alauddin Makassar
} 


\section{PENDAHULUAN}

\section{A. Latar Belakang}

Arsitektur tradisional adalah karya dari pewarisan/penerusan normanorma adat istiadat atau pewarisan budaya yang turun temurun dari generasi ke generasi. Keberadaan kampung tradisional sebagai jawaban atas tuntutan kebutuhan akan rumah dan kampung tempat tinggal bersama. Nenek moyang Suku Sasak membangun rumah dan perkampungan adat telah menggunakan teknologi dan arsitektur tersendiri sebagai manifestasi hasil cipta, karsa dan karya seni budaya di zamannya.

Desa adat Senaru atau kampung tradisional Senaru merupakan salah satu jalan menuju jalur pendakian Gunung Rinjani di Pulau Lombok di atas ketinggian $601 \mathrm{mdpl}$. Desa ini berada di kaki Gunung Rinjani, dan berjarak hanya 50 meter dari kantor pengelola Taman Nasional Gunung Rinjani. Dari berbagai narasumber dan referensi mengenai sejarah kebudayaan Propinsi NTB, diperoleh informasi bahwa Gunung Rinjani sebagai gunung tertinggi di Pulau Lombok yang dianggap memberikan kekuatan gaib dan berkah bagi masyarakat Sasak (Adonis, 1989).
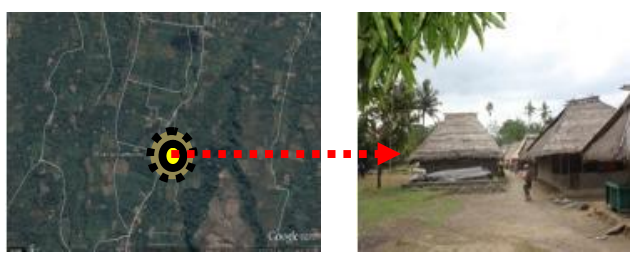

Gambar 1. Peta Lokasi Kampung

Tradisional Suku Sasak di

Desa Senaru

Sumber: Dokumentasi Field Trip, 2014

Desa Senaru adalah desa yang terletak di Kecamatan Bayan Kabupaten
Lombok Barat. Penduduk asli kampung ini dinamakan Suku Sasak. kata Senaru sendiri berarti Sinar Aru atau gadis. Sinaru sejati adalah nama yang diberikan untuk anak pertama yang lahir di Lombok ketika itu, karena kehadiran anak tersebut memberi kecerahan bagi pulau ini. Nama itu kemudian diambil untuk desa adat ini. Mata pencaharian masyarakat adalah sebagian besar bercocok tanam dan beternak telur puyuh. Jumlah penduduk yang mendiami kampung tradisional ini adalah 79 orang yang terdiri atas 20 Kepala Keluarga (KK), sesuai dengan jumlah rumah yanga ada di desa adat ini. Setiap rumah umumnya dihuni oleh Bapak, Ibu dan beberapa orang anak saja. Seluruh penduduk di perkampungan tradisional Desa Senaru ini beragama islam.

\section{TINJAUAN TEORI}

\section{A. Genius Loci}

Genius loci dalam arsitektur, secara harfiah adalah jiwa dari ruang dan waktu, lokalitas dan region-region di mana arsitektur tumbuh dan berkembang. Di dalamnya tercakup pelaku-pelaku, pengguna-pengguna, penatap-penatap, penikmat-penikmat dan keseluruhan masyarakat yang merasa dekat dan terwakili dalam kesadaran dan pengharapannya. (Hasan:2000). Schulz (1979) juga menjelaskan 3 konsep penting dan saling berkaitan yaitu; karakter, identitas dan genius loci. Sedangkan genius loci merupakan suatu konsep dibalik aspek fisik dan kultural yang dapat diketahui melalui pemahaman yang mendalam terhadap faktor-faktor yang membentuknya. Jadi genius loci adalah semangat "tempat" (spirit of place) dimana semangat itu menjadikan suatu tempat itu dapat "hidup". 
B. Kaitan Tempat dan Genius Loci

Teori tempat timbul dari fenomena dan geografi fisik. Menetapkan spesifikasi pada pengalaman dalam beberapa masalah. Pendapat genius loci, atau semangat unik pada tempat. Tempat menawarkan cara untuk mempetahankan kerelatifan dalam teori modern pada sejarah penggambaran tubuh dan verivikasinya pada kualitas utama pada sisi. Sedangkan peranan seorang arsitek disini adalah menghubungkan alam dengan keadaan alam dan penggunaan landscape.

\section{Teori Christian Norberg-Schulz The Phenomenon of Place}

Tempat merupakan bagian dari eksistensi. Tempat juga menentukan karakter sebuah lingkungan, yang merupakan esensi dari sebuah tempat. Tempat tidak dapat dideskripsikan secara analitik. Tempat memiliki arti lebih dari sekedar lokasi. Tempat memiliki arti yang sangat kaya tergantung dari sisi apa kita mengartikannya. Konsep dari genius loci menunjukan esensi dari sebuah tempat. Tempat berkorespondensi dengan semua unsur -unsur yang berada baik di dalamnya maupun di luarnya. Sebuah tempat yang hanya bisa mengakomodasi satu kegiatan akan segera menjadi sia-sia. Identifikasi dan orientasi merupakan hal utama dari keberadaan manusia di dunia, dimana identifikasi merupakan dasar dari perasaan memiliki. Objek dari identifikasi adalah lingkungan yang nyata yang biasanya kita lihat dan alami ketika kita tumbuh di saat masa kanakkanak.

\section{METODE PENELITIAN}

Metode penelitian dilakukan melalui field trip (kunjungan lapangan) dengan pengamatan kondisi permukiman, dan penggambaran tatanan permukiman khususnya genius loci ruang yang terlihat dan diketahui melalui wawancara dengan masyarakat saat survey, serta sketsa gambaran kawasan, Selanjutnya metode deskriptif dilakukan untuk meninjau karakeristik kawasan Dusun Senaru dan mengeksplorasi sosial budayanya sebagai manifestasi dari masih eksisnya kawasan ini sebagai perkampungan tradisional Suku Sasak.

\section{HASIL DAN PEMBAHASAN}

\section{Sejarah Masyarakat Suku Sasak}

Asal-usul etnik Sasak di Pulau Lombok dapat dikaji dari kata sasak sendiri. Sasak secara etimologi, menurut Goris S, berasal dari kata sah yang berarti "pergi" dan shaka yang berarti "pergi ke tanah leluhur". Dari etimologi ini diduga leluhur orang Sasak adalah orang Jawa, hal ini juga terbukti pula dari aksara Sasak yang oleh penduduk Lombok disebut "Jejawan", yakni aksara Jawa, yang selengkapnya diresepsi oleh kesusastraan Sasak. Suku Sasak adalah kelompok etnik mayoritas yang jumlahnya kurang lebih $90 \%$ dari total penduduk Lombok. Kelompokkelompok lain, seperti Bali, Sumbawa, Jawa, Arab, dan Cina, merupakan kelompok pendatang. Selain jumlah etnik yang beragam, pulau Lombok juga memiliki beragam budaya, bahasa, dan agama. Masing-masing kelompok berbicara berdasarkan bahasanya sendiri-sendiri. Orang Sasak, Bugis, dan Arab mayoritas beragama islam; orang Bali beragama Hindu; dan orang-orang Cina beragama Kristen.

Berdasarkan

kebiasaan keagamaan mereka, Sasak bisa dibagi ke dalam wetu lima dan wetu telu.waktu lima ditandai dengan ketaatan tinggi terhadap ajaran islam sesuai dengan waktu shalat lima waktu. Sedangkan waktu telu adalah ritual waktu tiga kali seminggu yaitu senin, jum'at, dan sabtu. Waktu ini diperuntukkan bagi mereka yang tetap memuja para leluhur, berbagai dewa dan lain-lain dalam 
lokalitas mereka. Walaupun bagi orang Sasak mayoritas islam, dalam kehidupan sehari-hari mereka, adat cenderung memerankan peran dominan di kalangan komunitas wetu telu, dan masih ada beberapa hal yang bertentangan dengan agama islam.

\section{Permukiman Tradisional Desa \\ Senaru}

Pada umumnya lokasi kampung adat terletak pada daerah atau dataran yang tinggi serta dikelilingi oleh hutan kecil. Hal tersebut dimaksudkan sebagai strategi keamanan, karena dengan lokasi yang tinggi dan terlindung pepohonan akan memudahkan dalam mengawasi lingkungan sekitarnya. Sebagian dari permukiman masyarat Suku Sasak terletak pada daerah pegunungan, namun demikian lokasi kampung adatnya tetap memilih pada lokasi /tempat yang cukup tinggi. Pola kampung adat pada umumnya berorientasi arah Utara-Selatan, dengan arah Selatan sebagai arah utama. Arah Selatan merupakan arah datangnya angin laut dari musim yang mendatangkan kesuburan dan hasil laut yang melimpah bagi masyarakat. Untuk menghormati anugerah alam inilah maka arah Selatan memperoleh penghargaan tinggi dan dijadikan sumbu utama dalam mewujudkan permukiman kampung adat (Senaru) masyarakat Sasak. Oleh sebab itu kampung tradisional Suku Sasak berorientasi Utara menghadap Selatan.

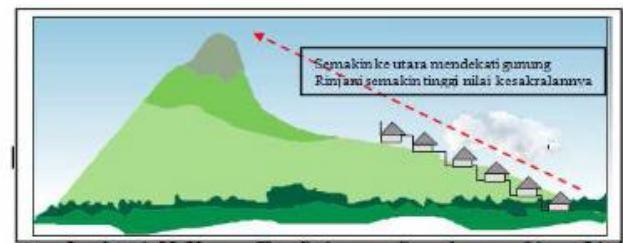

Gambar 2. Pola Bangunan terhadap Gunung Rinjani

Gunung Rinjani sebagai tempat yang dianggap memberikan kekuatan gaib dan berkah bagi masyarakat Sasak, berlanjut pada sistem kepercayaan yang dianut oleh masyarakat Desa Senaru adalah kepercayaan serba roh . dalam konsep bermukim, pemilihan lokasi permukiman pun masih mengandalkan faktor kepercayaan kosmos. Tidak hanya itu, tradisi budaya mereka yang menjadikan senior dalam keluarga memegang peranan penting, menuntut untuk mewujudkan hal itu dalam tatanan ruang mereka (Sasongko, 2005;35). Namun faktanya, di Desa Senaru secara turun temurun pada permukiman tradisional Suku Sasak secara, perubahan selera pada beberapa bangunan di Desa Senaru, dan terjadi penurunan tingkat kesadaran masyarakat Desa Senaru terhadap pentingnya upacara tradisional secara prinsip.

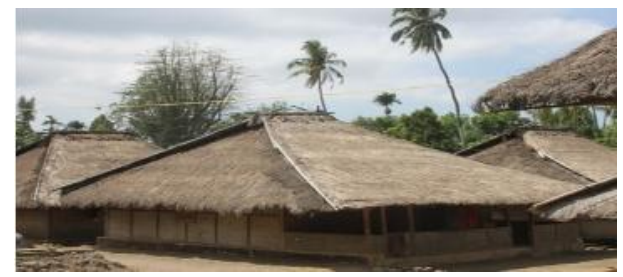

Gambar 3. Permukiman Suku Sasak di Desa Senaru

Sumber : Dokumentasi Field Trip, 2014

\section{Genius Loci pada Skala Makro (Permukiman)}

Genius Loci pada permukiman tradisional Sasak berupa beruga. Setiap rumah di kawasan ini selalu berorientasi terhadap berugaq. Arah pintu Bale selalu meghadap ke berugaq. Beruga ini berfungsi sebagai tempat berkumpulnya para pelaku upacara adat, misalnya merariq, tempat bersantai keluarga, ruang makan bagi laki-laki dan tempat menerima tamu. Pola perletakan sejajar memanjang dari arah Utara-Selatan. Pembangunan bale dilakukan dengan konsep cermin atau berhadapan, dan beruga ini terletak diantara dua bale. Umumnya pada saat beruga digunakan untuk menerima tamu, dilakukan upacara penyambutan dengan tari-tarian yang menceritakan keindahan alam Desa Senaru yaitu tentang air terjun dan Gunung Rinjani.

Jumlah beruga di perkampungan tradisional Suku Sasak Desa Senaru 
adalah 10 buah dimana rasio perbandingan 2 bale atau rumah untuk 1 beruga. Jarak antar hunian satu dengan lainnya yang dipisahkan dengan koridor jalan tanah adalah 2 meter. Kondisi jalan masih berupa jalan tanah. Menurut kepercayaan masyarakat Suku Sasak, permukaan jalan tidak boleh dibuat perkerasan atau diubah karena bertentangan dengan aturan adat dari nenek moyang mereka, jadi harus tetap dipertahankan keasliannya.

Beruga yang ada di depan rumah, di samping merupakan penghormatan terhadap rezeki yang diberikan Tuhan, juga berfungsi sebagai ruang keluarga, menerima tamu, juga menjadi alat kontrol bagi warga sekitar. Misalnya, kalau sampai pukul Sembilan pagi mereka masih ada yang duduk di beruga dan tidak keluar rumah untuk bekerja di sawah, ladang, dan kebun, mungkin dia akan sakit.

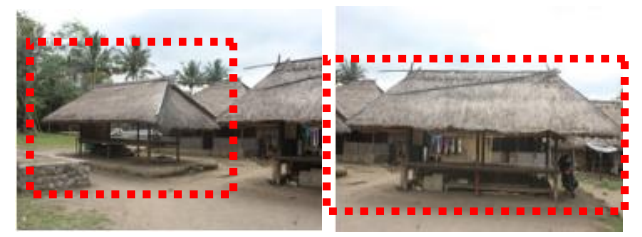

Gambar 4. Beruga di Kampung Tradisional Desa Senaru

Sumber : Dokumentasi Field Trip, 2014

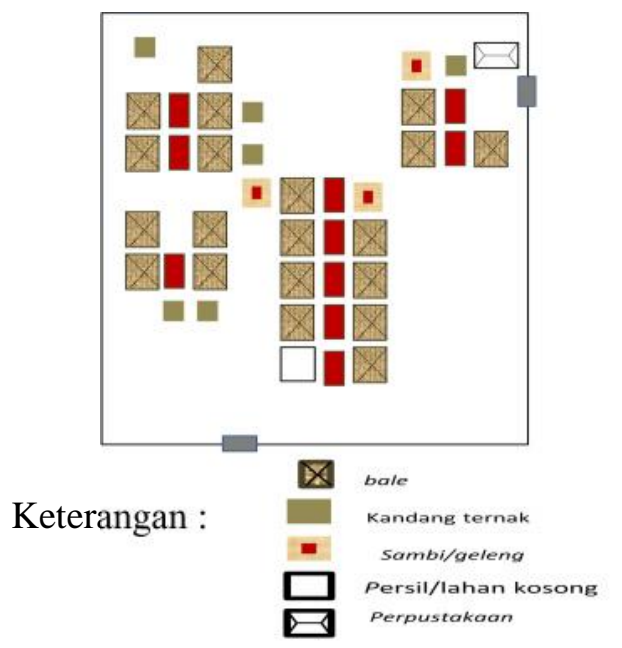

Gambar 5. Pola Permukiman Horizontal Kampung Tradisional Suku Sasak Desa Senaru
Selain bale, elemen ruang lain yang terdapat pada kampung tradisional suku Sasak di Desa Senaru (sesuai gambar 5):

1. Sambi, merupakan tempat menyimpan hasil pertanian masyarakat pada bagian atasnya, sedangkan bagian bawahnya dipergunakan sebagai tempat penyimpanan kayu bakar dan peralatan lainnya yang digunakan saat bertani dan bercocok tanam. Bentuk samba di kampung tradisional ini mempunyai empat tiang kayu.

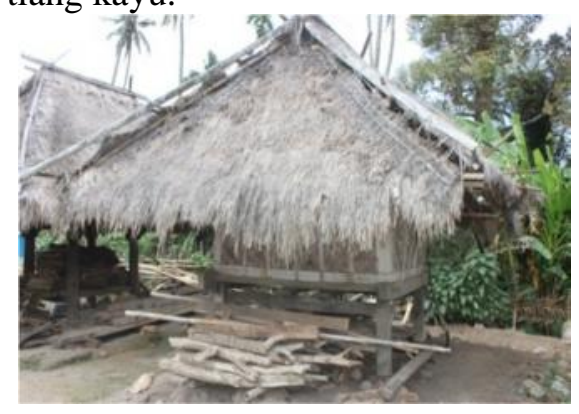

Sambi ini dilengkapi dengan tangga untuk naik dan didalamnya juga memiliki tangga untuk turun. Untuk membuka ruang bawah atap sambi ini biasanya dilakukan oleh laki-laki dengan posisi menolak ke atas (didorong). Jumlah samba pada perkampungan ini adalah 3 buah.

2. Kandang ternak letaknya di bagian belakang hunian atau pinggir deretan bale, hal ini karena kandang ternak dianggap kotor sehingga harus berada di luar.

3. Perpustakaan ini terbangun dari bantuan pihak pemerintah melalui program PNPM Pariwsata. Namun bangunan ini belum terlalu difungsikan sebagai perpustakaan.

Tatanan ruang permukiman ditata menurut hirarki sesuai dengan kepercayaan mereka. Elemen bangunan yang dianggap memiliki nilai tinggi ditempatkan pada bagian depan, dan secara berurutan yang bernilai sakral lebih rendah diletakkan di bagian belakang. Peletakan bangunan seperti ini 
membentuk pola permukiman berhirarki.

\section{Genius Loci pada Skala Mikro (Rumah Tinggal)}

Rumah tinggal di kampung tradisional Sasak disebut bale.secara sistem, pola bermukim pada rumah tinggal di kampung ini berdasarkan sistem kekerabatan. Pewarisan bale di Desa Senaru bersifat patrilokal, yaitu berdasarkan garis keturunan laki-laki. Sistem pewarisan tersebut memelihara dan mendukung konsep kekerabatan yang dimiliki oleh masyarakat Dusun Senaru sekaligus menjaga kepemilikan dan penghuni yang tinggal di Desa Senaru adalah masyarakat asli Desa Senaru. Bale-bale di Desa Senaru didirikan di atas tanah datar yang berada di daerah lereng. Di kelilingi oleh pagar dan berfungsi sebagai pembatas, pertahanan dan sebagai penyedia kelengkapan untuk upacara tertentu. Pembangunan bale dilakukan dengan konsep cermin atau berhadapan, Di luar bangunan rumah dekat pagar berdiri kandang ternak. Konsep pemujaan pada sepengkula juga diwujudkan pada sepengkula dalam perumahan, yakni pembangunan bale dibuat berdasarkan senioritas dalam sistem kekerabatan. Kriteria pembangunan adalah: tinggi rendah dan orientasi matahari. Pemilihan bale dan bahan sangat tergantung pada status sosial yang dimiliki.

Genius loci pada rumah tinggal atau bale suku Sasak adalah lumbung. Lumbung tidak sama dengan sambi dan alang, karena letaknya didalam rumah. Fungsinya adalah untuk menyimpan segala kebutuhan, posisi lantainya 1,5 meter dari lantai dasar rumah, dan ruangannya tertutup. Lantai lumbung terbuat dari bambu. Lumbung ini juga dipergunakan dan dibuka pada saat ada ritual adat. Sedangkan ruangan terbuka di samping lumbung merupakan ruang makan bagi perempuan (tidak diperuntukkan bagi wanita yang sedang haid) dan sering juga difungsikan sebagai ruang tidur bagi pengantin baru yang merupakan keturunan Sasak wajib bermalam di tempat ini. Namun setelah itu, mereka harus keluar mencari rumah sendiri agar bisa hidup mandiri.

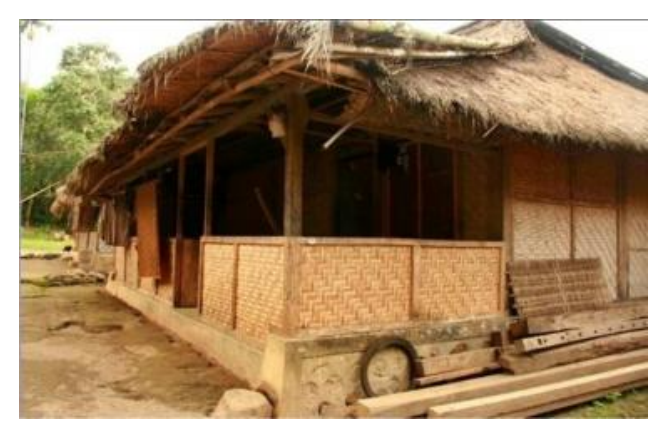

Gambar 6. Hunian atau bale di Kampung Tradisional Suku Sasak Desa Senaru

Sumber : Sketsa Field Trip, 2014

Sejak proses perencanaan rumah didirikan, peran perempuan atau istri diutamakan. Misalnya, jarak usuk bamboo rangka atap selebar kepala istri, tinggi penyimpanan alat dapur (sempare) harus dicapai lengan istri, bahkan lebar pintu rumah seukuran tubuh istri. Membangun dan merehabilitasi rumah dilakukan secara gotong royong meski makan-minum, berikut bahan bangunan disediakan oleh tuan rumah.

Untuk membangun rumah, dicari waktu yang tepat, berpedoman pada papan warige yang berasal dari primbon Tapel Adam dan Tajul Muluq. Tidak semua orang mempunyai kemampuan untuk menentukan hari baik, biasanya orang yang hendak membangun rumah adalah pada bulan ketiga dan bulan kedua belas penanggalan Sasak., yaitu bulan Rabiul Awal dan Zulhijjah pada kalender islam. Ada juga yang membangun rumah dengan menentukan hari baik berdasarkan nama orang yang akan membangun rumah. Sedangkan pantangan dalam membangun rumah adalah tidak boleh membangun pada 
bulan Muharram dan Ramadhan. Pada kedua bulan ini, menurut kepercayaan masyarakat setempat, rumah yang dibangun cenderung mengundang malapetaka, seperti penyakit, kebakaran, kesulitan rezeki, dan lain-lain.

Selain faktor waktu, pantangan lain dalam mendirikan rumah adalah faktor lokasi. Mereka meyakini bahwa lokasi yang tidak tepat berarti kurang baik kepada orang yang menempatinya. Misalnya, rumah di atas bekas perapian tidak boleh dibangun, bekas tempat pembuangan sampah, bekas sumur, dan posisi tusuk sate atau susur gubug. Selain itu, mereka juga tidak akan membangun rumah berlawanan arah dan ukurannya berbeda dengan rumah yang sebelumnya sudah ada. Menurut mereka, melanggar konsep tersebut adalah hal yang tabu.

\section{KESIMPULAN DAN SARAN}

1. Pemilihan lokasi permukiman Suku Sasak masih mengandalkan faktor kepercayaan kosmos, dimana Arah selatan dijadikan arah utama dalam bermukim.

2. Genius loci skala makro pada kawasan permukiman adalah beruga, karena setiap rumah di perkampungan tradisional Suku Sasak Desa Senaru berorientasi pada beruga. Sedangkan genius loci pada skala mikro (rumah/bale) adalah lumbung dalam.

3. Pembangunan bale dilakukan dengan konsep cermin atau berhadapan, Kriteria pembangunannya adalah: tinggi rendah dan orientasi matahari, serta pemilihan bale dan bahan sangat tergantung pada status sosial yang dimiliki.

\section{DAFTAR PUSTAKA}

Adonis. 1989. Suku Terasing Sasak Di Bayan Daerah Propinsi Nusa Tenggara Barat. Jakarta: Departemen Pendidikan dan Kebudayaan Direktorat Jenderal
Kebudayaan Direktorat Sejarah dan Nilai-Nilai Tradisional Proyek Inventasrisasi dan Pembinaan NilaiNilai Budaya.

Anonim. 2001. Rencana Induk Pengembangan Pariwisata Propinsi Nusa Tenggara Barat. Pemerintah Propinsi Nusa Tenggara Barat.

Sasongko, I. 2002. Transformasi Struktur Ruang Pada Permukiman Sasak, Kasus: Permukiman Tradisional Desa Puyung, Jurnal ASPI. 2, (1): 117125.

Soeroto, M. 2003. Dari Arsitektur Tradisional Menuju Arsitektur Indonesia. Jakarta: Ghalia Indonesia. 